\title{
Investigations of Acacia modesta Wall. leaves for in vitro anti-diabetic, proliferative and cytotoxic effects
}

\author{
Bushra Saleem", Muhammad Islam¹, Hamid Saeed², Fariha Imtiaz ${ }^{1}$, Maryam Asghar ${ }^{1}$, \\ Zikria Saleem $^{3}$, Azra Mehmood ${ }^{4}$, Surriya Naheed ${ }^{5}$
}

\begin{abstract}
${ }^{1}$ Section of Pharmaceutical Chemistry, University College of Pharmacy, University of the Punjab, Allama Iqbal Campus, Lahore, Pakistan, ${ }^{2}$ Section of Biomedical Sciences, University College of Pharmacy, University of the Punjab, Allama Iqbal Campus, Lahore, Pakistan, ${ }^{3}$ Section of Pharmacy Practice, University College of Pharmacy, University of the Punjab, Allama Iqbal Campus, Lahore, Pakistan, ${ }^{4}$ Center of Excellence in Molecular Biology, University of the Punjab, Thokar Niaz baig, Lahore, Pakistan, ${ }^{5}$ Section of Pharmaceutical Chemistry, Institute of Pharmacy, Lahore College for Women University, Jail Road, Lahore, Pakistan
\end{abstract}

\begin{abstract}
The leaves of Acacia modesta Wall. have been shown to possess diverse pharmacological properties. Therefore, we aimed at evaluating anti-diabetic, cytotoxic and proliferative effects of extracts of Acacia modesta Wall. leaves. After evaluating the primary and secondary metabolites, anti-diabetic activity of various extracts was assessed by $\alpha$-amylase inhibition, glucose uptake by yeast cells and non-enzymatic glycosylation of hemoglobin assay. Cytotoxicity and proliferative potential was assessed by MTT (3-(4,5-dimethylthiazol-2-yl)-2,5-diphenyltetrazolium bromide) and short term proliferation assays, respectively, using human liver carcinoma cell line, HepG2. Among other extracts, chloroform extract exhibited $34.16 \%$ inhibition of $\alpha$-amylase, $90.65 \%$ inhibition of hemoglobin glycosylation and $94.75 \%$ glucose uptake employing $\alpha$-amylase inhibition, non-enzymatic glycosylation of hemoglobin and glucose uptake by yeast cells assays, respectively. Moreover, extracts exhibited no significant effects on HepG2 cell viability and proliferation. So, this data suggested that chloroform extract of leaves of Acacia modesta Wall., exhibited higher anti-hyperglycemic activity in comparison to extracts in other solvents, while no extract demonstrated cytotoxic and proliferation effects when tested using HepG2 cell line.
\end{abstract}

Keywords: Acacia modesta Wall./anti-diabetic effects/cytotoxic/in vitro. MTT. Phytochemical.

\section{INTRODUCTION}

Medicinal plants are considered pivotal in curing many diseases and persistently provide benignant remedies (Duraipandiyan, Ayyanar, Ignacimuthu, 2006). Despite recent advancements in synthetic drug research, more than $25 \%$ of the medicines are derived either directly or indirectly from natural products, like Glucophage (metformin), a well-known anti-diabetic drug, which was derived from Galega officinalis (Grover, Yadav, Vats, 2002; Newman, Cragg, Snader, 2000). Globally, plants have frequently been used in the production of drugs due to augmenting research on phytochemicals for diverse biological activities (Kianbakht, Jahaniani,

*Correspondence: H. Saeed. University College of Pharmacy, Punjab University, Lahore, Pakistan. E-mail: hamid.pharmacy@pu.edu.pk
2003). Pakistan has varied climatic zones with unique biodiversity of medicinal herbs scattered over the large area. In Pakistan, a large number of medicinal plants (1572 genera and 5521 species) have been identified but only 600 plant species are used for medicinal purposes (Ali, 2008). Acacia modesta Wall, commonly known as Phulai and locally called Palosa (in Pashto), has traditionally being used for medicine, fuel and timber purpose, in Pakistan (Khan et al., 2014). Numerous literature evidences suggested that Acacia modesta Wall., possesses various pharmacological properties to treat skeletomuscular problems with regards to backaches in women after delivery and chronic stomach disorders (Murad et al., 2011). Leaves extract of Acacia modesta Wall. has been shown to possess in-vivo anti-hyperglycemic activity in alloxan induced diabetic rats (Jawla, Kumar, Khan, 2011). Methanolic leaves extract possesses analgesic, 
anti-platelet and anti-inflammatory properties, while anti-oxidant potential was affirmed through multiple anti-oxidant models including DPPH scavenging assay, hydrogen per oxide scavenging activity, super oxide radical scavenging assay and ABTS scavenging activity (Bukhari et al., 2010; Khan et al., 2014; Napar et al., 2012; Rahaman, Chaudhry, 2015). Hepatoprotective potential of the bark extracts of Acacia modesta Wall. has also been reported in which serum levels of hepatic metabolic enzymes and plasma proteins levels were used to analyze hepatotoxicity (Rahaman, Chaudhry, 2015). Anti-microbial properties of different extracts of stem and leaves have also been evaluated leading to extensive use of young twigs of this plant as 'miswak' (tooth stick) (Asghar et al., 2003; Khalid et al., 2011; Khan et al., 2014; Napar et al., 2012).

As reported previously, in-vivo anti-hyperglycemic effects of leaves extracts of Acacia modesta Wall. have been studied on normal glucose loaded rats, however, the results were merely significant at a dose of $300 \mathrm{mg}$ after 90 and 120 minutes (Jawla, Kumar, Khan, 2011). Various studies suggested that after proper clinical evaluation, plant extracts or other known bioactive molecules can be used along with the standard drugs as an adjuvant therapy in diabetes mellitus (Arif et al., 2014). As of today, use of medicinal plants in the management of diabetes is still frequently employed (Kooti et al., 2016; Kooti et al., 2015). Similarly, numerous studies have also reported the use of human carcinoma cell lines for screening of potential cytotoxic and proliferative effects of plant extracts in an attempt to identify novel medicinal and bioactive compounds of clinical relevance (Aydemir et al., 2015; Hamidinia, Ramezani, Mojtahedi, 2013).

As per the literature searches, no reports have been published with regards to cytotoxic and proliferation effects of leaves extracts of Acacia modesta Wall. Therefore, we aimed at evaluating the in vitro cytotoxic and proliferative effects of Acacia modesta Wall. leaves extracts using human liver carcinoma cell line- HepG2 along with anti-diabetic effects of these extracts using alpha amylase inhibition, glucose uptake by yeast cells and non-enzymatic glycosylation of hemoglobin assay.

\section{MATERIAL AND METHODS}

\section{Plant material, chemicals and reagents}

In November 2015, the leaves of Acacia modesta Wall. were collected from Chakwal, Punjab, Pakistan and were identified and authenticated from Department of Botany, Government College University, Lahore, Pakistan
(GC Herb. Bot. 2940). The leaves were separated, washed with water and shade dried at room temperature for 10 days in Pharmaceutical Biochemistry Research Lab-3, University College of Pharmacy, Punjab University, Lahore. After drying the leaves were sieved, pulverized and stored for later use.

Following chemicals and solvents of analytical grade were used, such as methanol, sodium chloride and sodium hydroxide (E. Merck A. G Darmstadt, Germany), sodium hydrogen phosphate, 3, 5-dinitro salicylicacid, potassium sodium tartrate (BDH, England), sodium dihydrogen phosphate (Riedel-de Haen, Germany), phosphoric acid, $\alpha$-amylase (UNI-CHEM), haemoglobin, yeast, glucose, gentamycin, acarbose (Glucobay 500) and tocopherol, anthrone Reagent (Sigma Life Sciences, Germany). For cell culture experiments following reagents were used; namely, Dulbecco's Modified Eagle medium (DMEM) and fetal bovine serum (FBS) (Hyclone, USA), penicillin and streptomycin solution (Hyclone, USA), dimethyl sulfoxide (DMSO) (Daejung, Korea), trypsin (Hyclone, UK), phosphate buffer saline (PBS) (Oxoid, England) and MTT reagent (Bio world, Dublin).

\section{Physicochemical analysis of powdered leaves}

The moisture content, total ash, acid insoluble ash, water soluble ash, sulphated ash and extractive values, alcohol and water soluble, were estimated according to USP procedures (USP, 2005).

\section{Determination of mineral contents}

Mineral contents of one gram of powdered leaves sample were estimated according to the protocol described previously (Ahmad et al., 2014).

\section{Extraction of plant leaves}

Different solvents including $\mathrm{n}$-hexane, chloroform, methanol, ethanol and water were used for extraction. Hot extraction was done by soxhlet apparatus using $n$-hexane, chloroform and methanol, while cold extraction was done by maceration using ethanol and water.

\section{Determination of primary and secondary Metabolites}

Primary metabolites should be including total proteins, lipids and carbohydrates were estimated according to protocols described previously (Al-Hooti, 
Investigations of Acacia modesta Wall. leaves for in vitro anti-diabetic, proliferative and cytotoxic effects

TABLE I - Physicochemical properties and mineral contents of powdered leaves Acacia modesta Wall.

\begin{tabular}{|c|c|c|c|c|c|c|c|}
\hline \multirow{4}{*}{$\begin{array}{l}\text { Sample } \\
\text { powder }\end{array}$} & \multicolumn{7}{|c|}{ Physicochemical properties } \\
\hline & $\begin{array}{c}\text { Moisture } \\
\text { content }\end{array}$ & Total ash & $\begin{array}{c}\text { Water soluble } \\
\text { ash }\end{array}$ & $\begin{array}{c}\text { Acid insoluble } \\
\text { ash }\end{array}$ & Sulphated ash & $\begin{array}{c}\text { Water soluble } \\
\text { extractive }\end{array}$ & $\begin{array}{c}\text { Alcohol soluble } \\
\text { extractive }\end{array}$ \\
\hline & $\begin{array}{c}\text { (\%contents } \\
\pm \text { SD) }\end{array}$ & $\begin{array}{c}\text { (\%contents } \\
\pm \text { SD) }\end{array}$ & $\begin{array}{l}\text { (\%contents } \\
\quad \pm \text { SD) }\end{array}$ & $\begin{array}{l}\text { (\%contents } \\
\quad \pm \text { SD) }\end{array}$ & $\begin{array}{l}\text { (\%contents } \\
\pm \text { SD) }\end{array}$ & $\begin{array}{l}\text { (\%contents } \\
\pm \text { SD) }\end{array}$ & $\begin{array}{l}\text { (\%contents } \\
\pm \text { SD) }\end{array}$ \\
\hline & $10.00 \pm 0.10$ & $9.96 \pm 0.15$ & $49.85 \pm 0.51$ & $5.00 \pm 0.10$ & $15.03 \pm 0.07$ & $4.22 \pm 0.05$ & $3.14 \pm 0.06$ \\
\hline & \multicolumn{7}{|c|}{ Mineral contents } \\
\hline \multirow[t]{2}{*}{$\begin{array}{l}\text { Sample } \\
\text { powder }\end{array}$} & & $\begin{array}{c}\text { Magnesium } \\
(\mathrm{mg} / \mathrm{g})\end{array}$ & $\begin{array}{c}\text { Iron } \\
(\mathrm{mg} / \mathrm{g})\end{array}$ & $\begin{array}{c}\text { Calcium } \\
(\mathrm{mg} / \mathrm{g})\end{array}$ & $\begin{array}{c}\text { Potassium } \\
(\mathrm{mg} / \mathrm{g})\end{array}$ & $\begin{array}{c}\text { Zinc } \\
(\mathrm{mg} / \mathrm{g})\end{array}$ & \\
\hline & & 6.32 & 4.84 & 2.17 & 1.22 & 0.030 & \\
\hline
\end{tabular}

Sidhu, Gabazard, 1998; Besbes et al., 2004; Lowry et al., 1951). While, secondary metabolites including total polyphenols, flavonoids, polysaccharides and glycosaponins were measured according to the protocols explained previously (Chang et al., 2002; Hussain et al., 2008; Slinkard, Singleton, 1977).

\section{In vitro anti- diabetic activity}

\section{Alpha amylase inhibition assay}

Alpha amylase inhibition assay was performed as described previously with some modifications (Kwon, Choi, Wang, 2007). Briefly, $1 \mathrm{~mL}$ of $\alpha$-amylase (1\% w/v in sodium phosphate buffer, $\mathrm{pH} 6.9$ ) and $1 \mathrm{ml}$ of sample solution $(1 \mathrm{mg} / \mathrm{mL})$ was taken and incubated at $37{ }^{\circ} \mathrm{C}$ for 5-15 minutes. Thereafter, $1 \mathrm{ml}$ of $1 \%$ starch solution $(1 \% \mathrm{w} / \mathrm{v}$ in sodium phosphate buffer, $\mathrm{pH}-6.9)$ was added and incubated for 15 minutes. Then, $1 \mathrm{~mL}$ of 3,5-dinitro salicylic acid color reagent was added and placed it in thermoregulatory water bath at $85^{\circ} \mathrm{C}$ for $5-10$ minutes. Later cooled at room temperature and the absorbance was measured at 540nm using UV-Visible spectrophotometer. Acarbose was used as a standard drug. Percentage inhibition was calculated by a formula in Equation 1.

EQUATION 1 - Determination of Percentage inhibition

$\%$ inhibition $=\frac{\text { Absorbance of control }- \text { Absorbace of sample solution }}{\text { Absorbance of control }} \times 100$

\section{Non-enzymatic glycosylation of hemoglobin assay}

Non-enzymatic glycosylation of haemoglobin assay was determined as described earlier (Parker et al., 1981) with slight modifications reported previously (Adisa et al., 2004). Briefly, $1 \mathrm{~mL}$ of $0.06 \%$ haemoglobin, $5 \mu \mathrm{L}$ of $0.02 \%$ gentamycin, $1 \mathrm{~mL}$ sample solution $(1 \mathrm{mg} / \mathrm{mL})$ and $1 \mathrm{~mL}$ of $0.2 \%$ glucose solution was mixed. The mixture was incubated for 72 hours at $37^{\circ} \mathrm{C}$ in dark environment.
Thereafter, the degree of glycosylation was measured at 443nm using UV-visible spectrophotometer. Tocopherol was used as a standard drug having similar concentration as that of extract sample solutions. \% inhibition was determined by using formula (Equation 1).

\section{Glucose uptake by yeast cells}

Glucose uptake was measured using yeast cells assay as described previously with some modifications (Bhutkar, Bhise, 2013). After preparing $10 \% \mathrm{v} / \mathrm{v}$ yeast cell suspension in ice cold normal saline, $1 \mathrm{ml}$ of sample $(1 \mathrm{mg} / \mathrm{mL}$ of all extracts) and $1 \mathrm{~mL}$ of $10 \mathrm{mM}$ glucose solution were mixed and incubated at $37^{\circ} \mathrm{C}$ for 10 minutes. Thereafter, $100 \mu \mathrm{L}$ yeast suspension was added, vortexed for 1 minute and incubated at $37{ }^{\circ} \mathrm{C}$ for an hour. After centrifugation at $3000 \mathrm{rpm}$ for 15 minutes, glucose was quantified in the supernatant by measuring absorbance at $620 \mathrm{~nm}$ using UV-visible spectrophotometer. The percentage increase in glucose uptake by yeast cells was calculated using formula (Equation 2).

EQUATION 2 - Determination of percentage increase of glucose by yeast cells

$\%$ increase in glucose uptake $=\frac{\text { Absorbance of control }- \text { Absorbace of sample }}{\text { Absorbance of control }} \times 100$

\section{Cytotoxic and proliferation assays}

The following dilutions, 50, 100 and $200 \mu \mathrm{g} / \mathrm{mL}$, of leaves extracts were used for cytotoxicity and proliferative effects on human liver carcinoma cell line - HepG2.

\section{Cell culture}

Human liver carcinoma cells (HepG2, liver hepatocellular cells) were maintained in DMEM medium with 10\% FBS (v/v), 1\% penicillin/streptomycin solution $(\mathrm{v} / \mathrm{v})$ at $37^{\circ} \mathrm{C}, 5 \% \mathrm{CO}_{2}$ and $95 \%$ relative humidity. 


\section{MTT assay}

MTT (3-(4,5-dimethylthiazol-2-yl)-2,5-diphenyltetrazolium bromide) assay was performed as described previously with slight modifications (Mosmann, 1983). Cells were plated in 96 well plate (flat bottom) at a density of 2000 cells/well. Next day, cells were treated with various concentrations of extracts $(50 \mu \mathrm{g} / \mathrm{mL}, 100 \mu \mathrm{g} / \mathrm{mL}$ and $200 \mu \mathrm{g} / \mathrm{mL}$ ). Thereafter, cells were incubated at $37^{\circ} \mathrm{C}, 5 \%$ $\mathrm{CO}_{2}$ and $95 \%$ relative humidity for 24 hours, while cells without test samples (extracts) were served as controls. After 24 hours incubation, $20 \mu$ l of MTT reagent $(5 \mathrm{mg} / \mathrm{mL}$ in DMSO) was added in each well with further incubation at $37^{\circ} \mathrm{C}$ for 4 hours. Afterwards, $80 \%$ of the medium with MTT was flicked off and the formed formazan crystals were solubilized in $150 \mu \mathrm{L}$ of DMSO and absorbance was measured at 500-600 $\mathrm{nm}$ in an ELISA reader.

\section{Short-term proliferation assay}

Short-term proliferation was assessed using protocol described previously (Saeed et al., 2012). Briefly, cells were plated in 4 well plates in triplicates at a density of 2000 cells/well. At $70 \%$ confluence, media was changed and control wells were fed with normal culture media while test wells were fed with culture media supplemented with extracts $-50 \mu \mathrm{g} / \mathrm{mL}$. Cells were counted manually using Neubauer chamber at day 1, 3 and 6 .

\section{Statistical analysis}

Mean and standard deviation of triplicate reading of each of the experiment was calculated using statistical formula. So, the data were expressed as mean \pm standard deviation. A two sample t-test using Microsoft Excel 2016 (Microsoft, USA) and $\mathrm{p}<0.05$ was considered statistically significant.

\section{RESULTS AND DISCUSSION}

Diverse climatic conditions of Pakistan are favorable for plants and approximately 2000 medicinal plant species have been reported, out of which only a few have been scrutinized for their definite physiological response in various ailments (Suganya, Sivakumar, 2014). Traditionally, Acacia modesta Wall has been used to treat number of ailments, such as leprosy, wound healing, dysentery, cough, venereal diseases, bacterial infection and backache. In the present study, the work has been extended to examine anti-diabetic, cytotoxic and proliferative potential of this valuable plant.

The extraction of Acacia modesta Wall. leaves was done through two methods, hot extraction using n-hexane, chloroform and methanol solvents while cold extraction using ethanol and water as solvents. The purpose for using two methods for extraction is to extract all possibly extractable compounds in the sample having potential affinities for respective solvents. As cold extraction is favorable for thermolabile compounds while hot extraction is suitable for thermostable compounds, so for that purpose both methods were employed by using both polar and non-polar solvents. Following USP procedures, data demonstrated that sample powder contains considerable amount of carbohydrates and proteins (Table II). Moreover, maximum glycosaponins contents were found in $\mathrm{n}$-hexane extract $(93.66 \pm 0.90 \mathrm{mg} / \mathrm{g})$, polysaccharides in methanol extract $(30.73 \pm 1.82 \mathrm{mg} / \mathrm{g})$, flavonoids in ethanol extract $(52.84 \pm 5.23 \mathrm{mg} / \mathrm{g})$ and polyphenols in aqueous extract $(108.04 \pm 5.02 \mathrm{mg} / \mathrm{g})$ (Table II).

Phytochemical analysis connoted that the leaves of Acacia modesta Wall. are effective source of carbohydrates, proteins and lipids which may contribute towards variety

TABLE II - Estimation of primary \& secondary metabolites of powdered leaves of Acacia modesta Wall.

\begin{tabular}{|c|c|c|c|c|}
\hline \multirow[t]{3}{*}{ Sample Powder } & \multicolumn{3}{|c|}{ Primary Metabolites } & \\
\hline & $\begin{array}{c}\text { Total Proteins } \\
(\mathrm{mg} / \mathrm{g} \pm \mathrm{SD})\end{array}$ & $\begin{array}{l}\text { Total Lipids } \\
(\mathrm{mg} / \mathrm{g} \pm \mathrm{SD})\end{array}$ & $\begin{array}{c}\text { Total Carbohydrates } \\
(\mathrm{mg} / \mathrm{g} \pm \mathrm{SD})\end{array}$ & \\
\hline & $17.18 \pm 0.47$ & $2.102 \pm 0.08$ & $60.76 \pm 0.42$ & \\
\hline & \multicolumn{4}{|c|}{ Secondary Metabolites } \\
\hline Sample Extracts & $\begin{array}{c}\text { Total Polysaccharides } \\
(\mathrm{mg} / \mathrm{g} \pm \mathrm{SD})\end{array}$ & $\begin{array}{c}\text { Total Polyphenols } \\
(\mathrm{mg} / \mathrm{g} \pm \mathrm{SD})\end{array}$ & $\begin{array}{c}\begin{array}{c}\text { Total Flavonoids } \\
(\mathrm{mg} / \mathrm{g} \pm \mathrm{SD})\end{array} \\
\end{array}$ & $\begin{array}{c}\text { Total Glyco-saponins } \\
(\mathrm{mg} / \mathrm{g} \pm \mathrm{SD})\end{array}$ \\
\hline n-Hexane & $16.77 \pm 0.40$ & $105.66 \pm 1.15$ & $5.53 \pm 0.09$ & $93.66 \pm 0.90$ \\
\hline Chloroform & $19.16 \pm 0.10$ & $104.86 \pm 2.47$ & $8.37 \pm 0.20$ & $60.33 \pm 1.53$ \\
\hline Methanol & $30.73 \pm 1.82$ & $104.71 \pm 2.44$ & $6.96 \pm 0.38$ & $35.83 \pm 2.45$ \\
\hline Ethanol & $23.43 \pm 0.98$ & $106.70 \pm 0.35$ & $52.84 \pm 5.23$ & $33.43 \pm 2.19$ \\
\hline Water & $17.13 \pm 0.84$ & $108.04 \pm 5.02$ & $5.53 \pm 0.20$ & $80.43 \pm 1.70$ \\
\hline
\end{tabular}


of pharmacological activities like anti-diabetic and anticancer effects.

Alpha-amylase is an intestinal digestive enzyme that hydrolyses polysaccharides to simple monosaccharides, thus playing imperative role in carbohydrates digestion (Chaudhari, Joshi, Mistry, 2013). The postprandial glucose level can be reduced to minimal levels by inhibiting alphaamylase, the similar concept was utilized for in vitro anti-diabetic effects in our study. As shown in Figure 1A, chloroform extract demonstrated considerable inhibition in $\alpha$-amylase activity, comparable to standard, followed by $n$-hexane, methanol, ethanol and water extracts (Figure 1A). Dose response relationship experiments, performed only for promising extract, i-e., chloroform, further suggested that $\alpha$-amylase inhibition increases with the increase in extract dose (chloroform), while the median inhibitory concentration $\left(\mathrm{IC}_{50}\right)$ was observed at a dose of $440 \mu \mathrm{g} / \mathrm{ml}$ (Figure 1B). Literature evidences frequently suggested that alpha-amylase inhibition assay is frequently supported by inhibition of hemoglobin glycosylation and glucose uptake by yeast cells (Sathiavelu et al., 2013; Suganya, Sivakumar, 2014). Therefore, anti-diabetic activity of leaves extracts were examined by employing non-enzymatic glycosylation of haemoglobin assay. As shown in Figure 1C, among various extracts, chloroform and n-hexane extracts demonstrated higher anti-diabetic activity compared to standard (tocopherol), while methanol, ethanol and aqueous extract exhibited comparable activities (Figure 1C). The dose response relationship of chloroform extract resulted in the median inhibitory concentration $\left(\mathrm{IC}_{50}\right.$ ) of $140 \mu \mathrm{g} / \mathrm{mL}$ (Figure 1D). Moreover, the glucose uptake by yeast cells experiments showed that in the presence of chloroform extract yeast cells exhibited maximum glucose uptake, even more than the standard, followed by n-hexane and methanol extracts (Figure 1E). Utilizing chloroform extract the median inhibitory concentration $\left(\mathrm{IC}_{50}\right)$ was found to be $120 \mu \mathrm{g} / \mathrm{ml}$ (Figure 1F).

These data suggested that chloroform extract contains higher amounts of polyphenols, glycosaponins and polysaccharides that possess strong anti-hyperglycemic activity. Compared to our findings another study (Jawla, Kumar, Khan, 2011) demonstrated that ethanol extracts of Acacia modesta Wall. leaves exhibited strong antihyperglycemic activity at a dose of $100 \mathrm{mg} / \mathrm{kg}$ in rat model of hyperglycemia. However, a direct comparison with our data cannot be made, because the extracting solvent, chloroform in our case, and dose are strikingly different, thus it is pertinent to further test chloroform extract in hyperglycemic mice or rat models using various doses.

Numerous studies have documented the use of human cancer cell lines for initial screening of medicinal
A

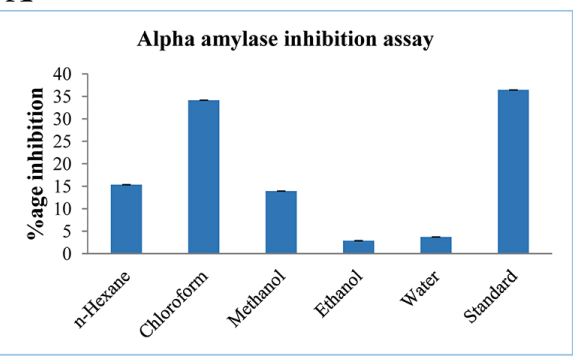

C

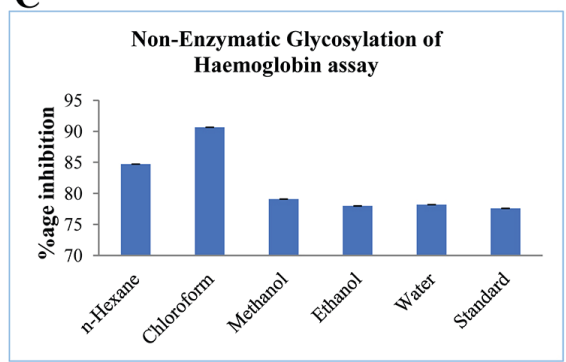

E

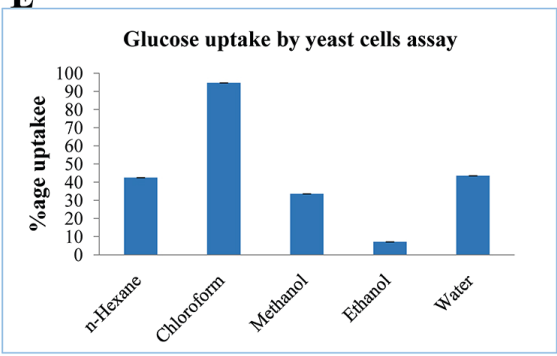

B

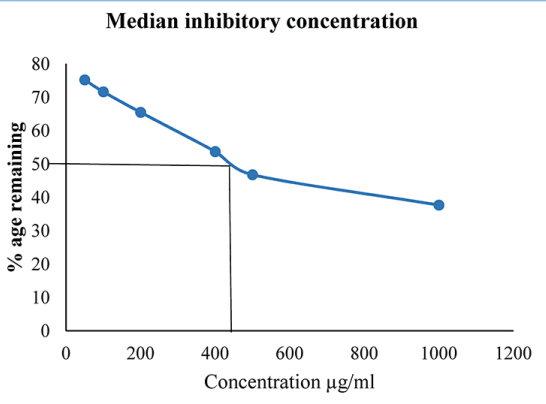

D

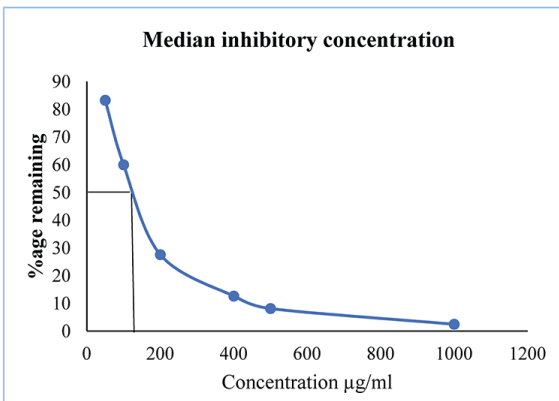

F

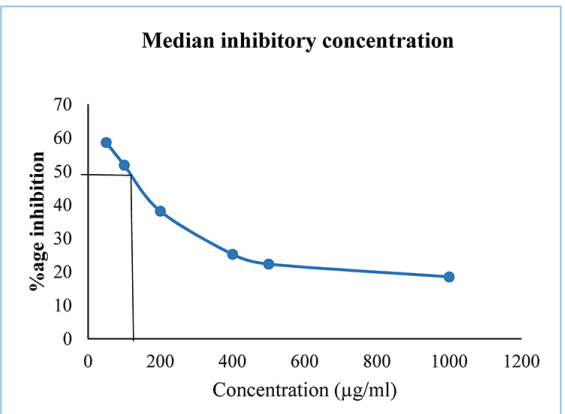

FIGURE 1 - Anti-diabetic Activity of Extracts of leaves of Acacia modesta Wall. A) Alpha amylase inhibition assay B) Dose response relationship of chloroform extract using alpha amylase inhibition assay $\mathbf{C}$ ) Non-enzymatic glycosylation of hemoglobin assay D) Dose response relationship of chloroform extract using non-enzymatic glycosylation of hemoglobin assay E) Glucose uptake by yeast cells assay F) Dose response relationship of chloroform extract using glucose uptake by yeast cells assay 
plants against cancer, for example taxol, paclitaxel and vinblastine were originally obtained from plant sources (Greenwell, Rahman, 2015; Pezzuto, 1996). In this context, MTT and short term proliferation assays are sensitive and reliable colorimetric assays, used routinely, for estimating cell viability and proliferation (Mosmann, 1983; Saeed et al., 2012). As per literature evidences polyphenols and glycosaponins have been shown to possess anti-cancer activity due it anti-angiogenic and anti-inflammatory potential (Siddiqui et al., 2009; Sorice et al., 2016). Thus, the leaves extracts were tested on HepG2 cell line, human liver carcinoma cell line, for cytotoxic and proliferative effects. Only aqueous and n-hexane extracts were employed for these studies due to non-availability or insufficient quantities of extracts available for these experiments. As shown in Figure $2 \mathrm{~A}$ and $\mathrm{C}$, when tested for different concentrations $(50,100$ and $200 \mu \mathrm{g} / \mathrm{mL})$, aqueous and $n$-hexane extracts exhibited no significant cytotoxic effects or on cell viability as demonstrated by MTT assay (Figure 2A \& C). Likewise, aqueous and $n$-hexane leaves extracts showed no significant effects on HepG2 cell proliferation, examined at day 1, 3 and 6 , as evident by short-term proliferation assay (Figure
2B \& D). Thus, the leaves extracts of Acacia modesta Wall. when tested on human liver cancer cell line, HepG2, the results neither exhibited any signs of cell toxicity nor any effect on cell proliferation - anti or pro proliferative. These data were further corroborated by short term proliferation assay at different time points. However, these effects cannot be generalized to other cancer cell lines due to cell type dependent variations.

\section{CONCLUSION}

In conclusion, our data suggested that Acacia modesta Wall. leaves possessed primary and secondary metabolites, such as protein, carbohydrate, lipids, polyphenols, flavonoids, glycosaponins and polysaccharides, which might contribute towards antidiabetic effects. Seemingly, chloroform extract exhibited maximum anti-hyperglycemic activity and might harbor higher amounts of glycosaponins and polyphenols. Furthermore, MTT and short term proliferation assays suggested that aqueous and $n$-hexane extracts neither possess cytotoxic nor anti-proliferative effects when tested
A

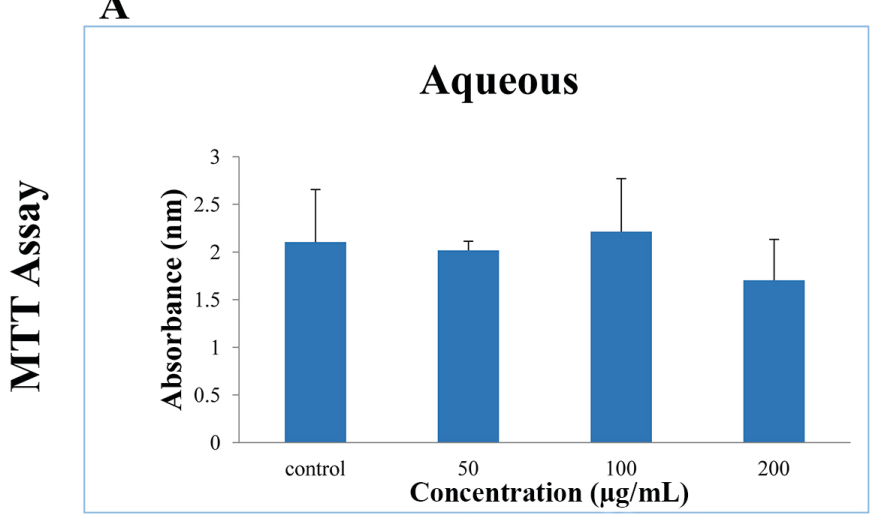

B

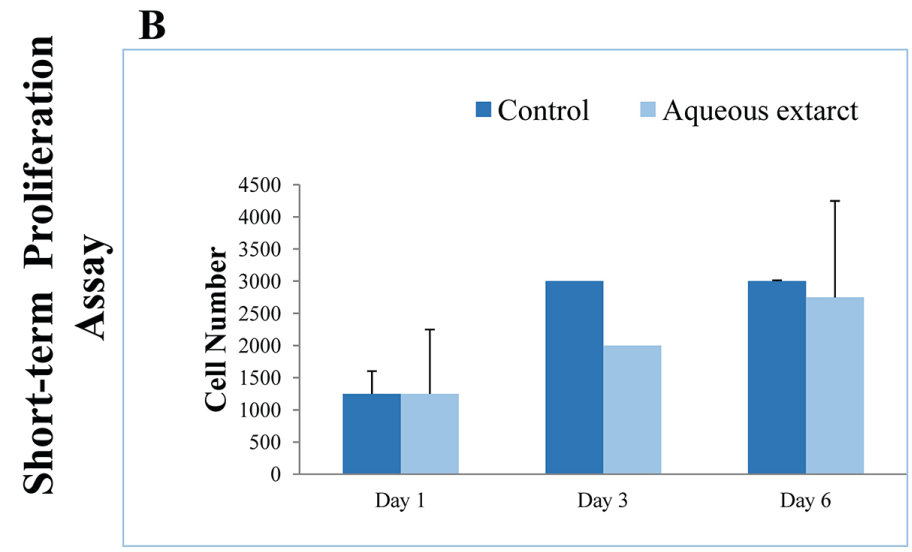

C

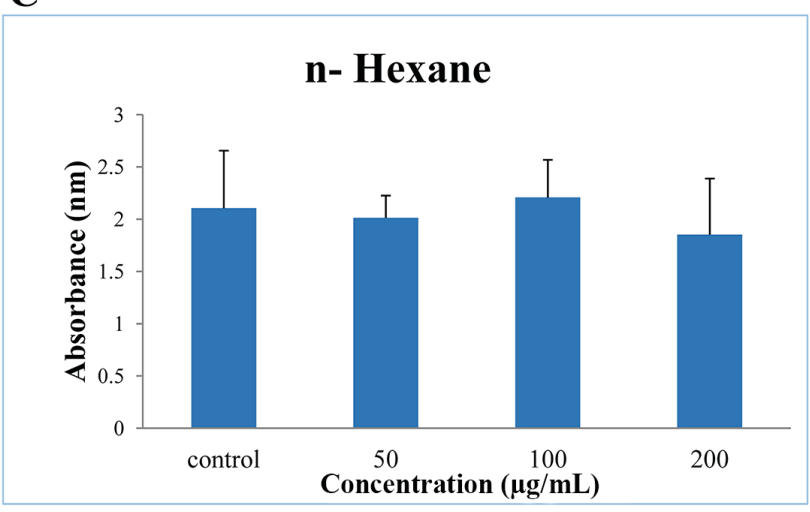

D

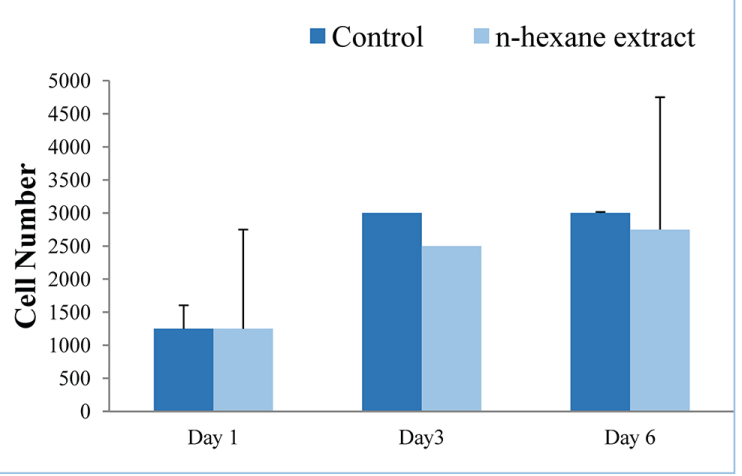

FIGURE 2 - Cytotoxic and Proliferative effects of Aqueous and n-hexane Extracts of Leaves of Acacia modesta Wall using HepG2 cell line. A) MTT assay of aqueous extract, B) Short-term proliferation assay of aqueous extract, C) MTT assay of $n$-hexane extract, D) Short term proliferation assay of n-hexane extract. 
on human liver carcinoma cell line, HepG2. Thus, further studies are required to examine the anti-diabetic effects of chloroform extracts using in vivo settings and chloroform extract should also be investigated for anti-cancer, antiproliferative effects using different primary (normal) and cancerous cells.

\section{ACKNOWLEDGEMENTS}

Authors are thankful to Dr. Azra for providing the HepG2 cell lines.

\section{CONFLICT OF INTEREST STATEMENT}

Authors declared no conflict of interests.

\section{FUNDING}

No funding was available for this project.

\section{REFRENCES}

Adisa RA, Oke J, Olomu SA, Olorunsogo O. Inhibition of human haemoglobin glycosylation by flavonoid containing leaf extracts of Cnestis ferruginea. J Cameroon Acad Sci. 2004;4(3):351-9.

Ahmad A, Husain A, Mujeeb M, Siddiqui NA, Damanhouri ZA, Bhandari A. Physicochemical and phytochemical standardization with HPTLC fingerprinting of Nigella sativa L. seeds. Pak J Pharm Sci. 2014;27(5):1175-82.

Al-Hooti S, Sidhu S, Gabazard H. Chemical composition of seeds of date fruit cultivars of United Arab Emirates. J Food Sci Technol. 1998;35(1):44-6.

Ali S. Significance of flora with special reference to Pakistan. Pak. J. Bot. 2008;40(3):967-71.

Arif T, Sharma B, Gahlaut A, Kumar V, Dabur R. Anti-diabetic agents from medicinal plants: A review. Chem Biol Lett. 2014;1(1):1-13.

Asghar R, Ahmad M, Zafar M, Akram A, Mahmood J, Hassan M. Antibacterial Efficacy of Acacia modesta Wall (Miswak) against Dental Pathogen. Pak J Biol Sci. 2003;6(24):2024-5.

Aydemir EA, Simsek E, Imir N, Göktürk RS, Yesilada E, Fiskin K. Cytotoxic and apoptotic effects of Ebenus boissieri Barbey on human lung cancer cell line A549. Pharmacogn Mag. 2015;11(Suppl 1):S37.
Besbes S, Blecker C, Deroanne C, Drira N-E, Attia H. Date seeds: chemical composition and characteristic profiles of the lipid fraction. Food Chem. 2004;84(4):577-84.

Bhutkar M, Bhise S. In vitro hypoglycemic effects of Albizzia lebbeck and Mucuna pruriens. Asian Pac J Trop Biomed. 2013;3(11):866-70.

Bukhari IA, Khan RA, Gilani AH, Ahmed S, Saeed SA. Analgesic, anti-inflammatory and anti-platelet activities of the methanolic extract of Acacia modesta leaves. Inflammopharmacology. 2010;18(4):187-96.

Chang C-C, Yang M-H, Wen H-M, Chern J-C. Estimation of total flavonoid content in propolis by two complementary colorimetric methods. J Food Drug Anal. 2002;10(3):178-82.

Chaudhari MG, Joshi BB, Mistry KN. In vitro anti-diabetic and anti-inflammatory activity of stem bark of Bauhinia purpurea. Bull Pharm Med Sci (BOPAMS). 2013;1(2):139-150.

Duraipandiyan V, Ayyanar M, Ignacimuthu S. Antimicrobial activity of some ethnomedicinal plants used by Paliyar tribe from Tamil Nadu, India. BMC Complementary Altern. Med. 2006;6(1):1.

Greenwell M, Rahman P. Medicinal plants: their use in anticancer treatment. Int J Pharm Sci Res. 2015;6(10):4103.

Grover JK, Yadav S, Vats V. Medicinal plants of India with anti-diabetic potential. J Ethnopharmacol. 2002;81(1):81-100.

Hamidinia M, Ramezani M, Mojtahedi Z. Cytotoxic/ proliferative effects of umbelliprenin on colon cancer cell lines. Ann Colorectal Res. 2013;1(3):101-5.

Hussain K, Ismail Z, Sadikun A, Ibrahim P. Analysis of proteins, polysaccharides, glycosaponins contents of Piper sarmentosum Roxb. and anti-TB evaluation for bioenhancing/interaction effects of leaf extracts with Isoniazid (INH). Nat Prod Radiance. 2008;7(5):402-8.

Jawla S, Kumar Y, Khan M. Antimicrobial and antihyperglycemic activities of Acacia modesta leaves. Pharmacologyonline. 2011;2:331-47.

Khalid A, Rehman U, Sethi A, Khilji S, Fatima U, Khan MI, et al. Antimicrobial activity analysis of extracts of Acacia modesta, Artimisia absinthium, Nigella sativa and Saussurea lappa against Gram positive and Gram negative microorganisms. Afr J Biotechnol. 2011;10(22):4574-80. 
Khan N, Ahmad M, Khan RA, Khan ST, Muhammad N. Investigation of Acacia modesta leaves for in-vitro antioxidant activity, enzyme inhibition and cytotoxicity. World Appl Sci J. 2014;30(3):286-93.

Kianbakht S, Jahaniani F. Evaluation of antibacterial activity of Tribulus terrestris L. growing in Iran. Iran J Pharmacol Ther. $2003 ; 2(1): 22-4$.

Kooti W, Farokhipour M, Asadzadeh Z, Ashtary-Larky D, Asadi-Samani M. The role of medicinal plants in the treatment of diabetes: a systematic review. Electr Physic. 2016;8(1):1832.

Kooti W, Moradi M, Akbari SA, Sharafi-Ahvazi N, AsadiSamani M, Ashtary-Larky D. Therapeutic and pharmacological potential of Foeniculum vulgare Mill: a review. J Herb Med Pharmacol. 2015;4(1):1-9.

Kwon G, Choi D, Wang M. Biological activities of hot water extracts from Euonymus alatus leaf. Korean J Food Sci Tech. 2007;39:569-74.

Lowry OH, Rosebrough NJ, Farr AL, Randall RJ. Protein measurement with the Folin phenol reagent. J Biol Chem. 1951;193(1):265-75.

Mosmann T. Rapid colorimetric assay for cellular growth and survival: Application to proliferation and cytotoxicity assays. J Immunol Methods. 1983;65(1):55-63.

Murad W, Ahmad A, Gilani SA, Khan MA. Indigenous knowledge and folk use of medicinal plants by the tribal communities of Hazar Nao Forest, Malakand District, North Pakistan. J Med Plants Res. 2011;5(7):1072-86.

Napar AA, Bux H, Zia MA, Ahmad MZ, Iqbal A, Roomi S, et al. Antimicrobial and antioxidant activities of Mimosaceae plants; Acacia modesta Wall (Phulai), Prosopis cineraria (Linn.) and Prosopis juliflora (Swartz). J Med Plants Res. 2012;6(15):29622970.

Newman DJ, Cragg GM, Snader KM. The influence of natural products upon drug discovery. Nat Prod Rep. 2000;17(3):21534.

Parker KM, England J, Da Costa J, Hess R, Goldstein D. Improved colorimetric assay for glycosylated hemoglobin. Clinical Chem. 1981;27(5):669-72.
Pezzuto J. Taxol production in plant cell culture comes of age. Nat Biotechnol. 1996;14(9):1083.

Rahaman MS, Chaudhry MA. Evaluation of antioxidant and hepatoprotective effect of Acacia modesta wall against paracetamol induced hepatotoxicity. Br J Pharm Res. 2015;5(5):336-43

Saeed H, Taipaleenmäki H, Aldahmash AM, Abdallah BM, Kassem M. Mouse embryonic fibroblasts (MEF) exhibit a similar but not identical phenotype to Bone Marrow Stromal Stem Cells (BMSC). Stem Cell Rev Rep. 2012;8(2):318-28.

Sathiavelu A, Sangeetha S, Archit R, Mythili S. In vitro antidiabetic activity of aqueous extract of the medicinal plants Nigella sativa, Eugenia jambolana, Andrographis paniculata and Gymnema sylvestre. Int J Drug Dev. Res. 2013;5(2):323-328.

Siddiqui M, Hafizoh S, Ismail Z, Sahib H, Helal M, Majid AA. Analysis of total proteins, polysaccharides and glycosaponins contents of orthosiphon stamineus benth. in spray and freeze dried methanol: water $(1: 1)$ extract and its contribution to cytotoxic and antiangiogenic activities. Pharmacogn Res. 2009;1(5):320.

Slinkard K, Singleton VL. Total phenol analysis: automation and comparison with manual methods. Am J Enol Vitic. 1977;28(1):49-55.

Sorice A, Siano F, Capone F, Guerriero E, Picariello G, Budillon A, et al. Potential anticancer effects of polyphenols from chestnut shell extracts: modulation of cell growth, and cytokinomic and metabolomic profiles. Molecules. 2016;21(10):1411.

Suganya G, Sivakumar R. In vitro antidiabetic, antioxidant and anti-inflammatory activity of Clitoria ternatea L. Int J Pharm Pharm Sci. 2014;6(7):342-7.

United States Pharmacopoeia. USP. D-1, Volume (1). Thomas PDR. Micromedex Drug Information for the Health Care Professional; 2005.

Received for publication on $30^{\text {th }}$ October 2017 Accepted for publication on $07^{\text {th }}$ December 2017 